\section{THE PLANE TREE}

\section{BY ALEXANDER L. HOWARD}

$\mathrm{T}$ RAVELLERS from warm and sunny countries criticize, quite rightly, the smoky atmosphere of London. It is a curious but fortunate fact that this damp and smoky climate, which retards the growth of nearly all forest trees, for some unknown reason invigorates the plane (Platanus orientalis Linn., $P$. occidentalis, $P$. acerifolia Willd.).

Throughout the City and its suburbs this lovely tree flourishes in all its grandeur and beauty, and completely outclasses other varieties introduced from foreign lands. For example, the acacia cannot live in England up to its national reputation in America, and has utterly failed to fulfil Cobbett's well-known claims.

It would probably be impossible to find a more beautiful avenue of trees than that which leads up the Mall to Buckingham Palace. These trees are now in their youth, and should grow in dignity for at least another two centuries, but already their spreading beauty in summer and their equally imposing winter aspect are unique. Planted and spaced at regular intervals, without failure or exception they have grown to a uniformity in size, both as regards the crown and the trunk. No other tree but the plane could be relied upon for such regularity of growth, and it is partly for this reason that it is so suitable for avenue and roadside planting.

Whilst all Londoners are familiar with its grace and beauty, and grateful for its cool shade in dusty summer heat, it is doubtful whether many realize the history of this interesting foreigner, which has become so happily naturalized in Great Britain. Indeed, such is our national ignorance and lack of education on this important subject, that only a small minority of English people know the difference between a plane and any other forest tree, despite its annual habit of shedding its bark, which is its own original and destructive way of keeping healthy.

Its tenacity and stubborn resistance to violent attack has been exemplified. "A fine plane tree can now be seen flourishing by the side of the Grand Junction Canal in London, close to the North Gate of Regent's Park leading to Avenue Road. It has an interesting history. In 1874 a barge containing petroleum, while passing up the canal, exploded with a report which was heard ten miles away. The bridge and the keeper's cottage were blown away, the plane tree being apparently destroyed. Thirty years after, the only part of the old trunk remaining was a dead, charred, pointed piece, which could be seen protruding through the new and vigorous growth around it; this dead piece has now disappeared (1932), and the only sign of the disaster which remains is an opening extending from the ground to about 10 feet from the present top of the tree. This opening is now closing, and it is safe to predict that in a very few years the trunk will no longer bear any evidence of the damage". This opening is now (1943) scarcely noticeable.

The Times has quoted another instance of what the contributor called "The Dauntless Tree", namely, the plane tree outside Stationers' Hall, which, "in spite of fire and bombs which stripped it of all its leaves and branches, put forth new leaf all up its abnormally straight stem, symbolising the dauntless spirit of London".

An admirable picture was produced in the Tree
Lover, entitled "Bath after the Blitz", showing five plane trees in the demolished Circus; it now transpires that these trees are much less damaged than was originally thought to be the case.

From earliest times history records examples of the prominent position held in arboriculture by the plane tree, which was introduced first into Greece, and afterwards into Italy, and afterwards throughout all Europe, southern Asia, and in Persia, where the magnificent 'Chenar' trees have been the pride of its people. Continual reference is made to the plane tree before and after the rise of the Roman Empire. About the year A.D. 530 Pliny tells us :

"But who would not marvel rather at this, that our people here should go into farre countries, and fetch a tree from thence, even out of another world, only for the shade that it giveth. For surely of fruitful trees Italie hath store ynouth. And what tree should that be but the very plane, brought first over the Ionian Sea into the island Djomedea, for to beautifie the tomb of Diomides. From thence translated into Sicilie and so bestowed at length upon Italie, and there planted, as a most regular, rare, and special tree. But now it is caried as far as Tetwin and Tournay in France, where it is counted an appertenance to the very soile that paieth tribute, insomuch, as people will but walke and refresh themselves under the shadow of it, must pay a custom therefore unto the people of Rome. Dionysius, King of Sicile, and the first of that name, caused them to be brought from Rheguim in Calabria to his roiall cittie, where his palace was, onely of a singularitie because they should be seen to give a shade before his house, where afterwards was made the Colledge or a place of public exercise."

and :

"Of a certaine region we have before written, called Aulocrene, lying in the way between Apamia and Phrygia : and there the paisants of that countrey can show you that very plane tree, on which Marsyas the musician hung himselfe in a melancholly mood, for that he was overmatched in his owne cunning and professed skill, by Apollo: And surely like it is, that even then he made choice of that tree for the bignesse."

\section{Evelyn says :}

"This beautiful and precious tree, originally sacred to Helena . . . was so doated on by Xerxes that Aelian"

\section{and other authors tell us:}

" $\mathrm{He}$ made halt and stopped his prodigious army of seventeen hundred thousand soldiers, which even covered the sea, exhausted rivers, and thrust Mount Athos from the Continent, to admire the pulchritude and procerity of one of them; and become so fond of it, that, spoiling both himself, his concubines, and great persons of all their jewels, he covered it with gold, gems, necklaces, scarfs, and bracelets, and infinite riches; in sum, was so enamoured of it, that for some days neither the concernment of his grand expedition, nor interest of honour, nor the necessary motion of his portentious army, could persuade him from it."

Elwes and Henry in "Trees of Great Britain and Ireland" tell us that Platanus orientalis was introduced into England some time before 1562; the Western plane $P$. occidentalis in 1636 ; and distinction was made of the botanical species $P$. acerifolia in 1703. They also enumerate a great number of outstanding examples, including one "planted by Bishop Gunning in the Palace Gardens at Ely in 1896. It was found by the shadow to be about 100 feet high and 23 feet in girth at 3 feet from the ground". At Mottisfont Abbey there is a magnificent tree which Elwes measured in $1898,29 \mathrm{ft} .8$ in. at $4 \frac{1}{2} \mathrm{ft}$. from 
the ground. This tree is remarkable on account of its gnarled growth. He also mentions one at Woolbending Rectory, Sussex, about $105 \mathrm{ft}$. high by no less than $25 \mathrm{ft}$. in girth, and directs attention to the triumphant beauty of the avenue at Cowdray Park. They also say :

"The planes in Berkeley Square are worth notice on account of their uniform burry trunks swelling at the base. . . . They were planted by Mr. Edward Bouverie in 1789 and are probably the oldest plane trees in London. According to Mr. Birkbeck the two largest, in 1906, girthed at 5 feet, 13 feet 10 inches and 13 feet 4 inches respectively, and were about 85 feet high. (The largest of these now measures 14 feet 9 inches in girth and 5 feet 1 inch in diameter at base.)

Tradition says that this was a burial ground during the Plague of London in 1665."

Although these trees grow to a magnificent size in England they do not compare with those of which Pliny writes as follows:

"and in truth this tree [the plane tree], and the situation thereof, is so admirable, that Licinius Mutianus, thrice Consul and late Lieutenant Generall and Governour of that Province, thought this thing worthie to be regarded as a memoriall to posteritie, when he and 18 more persons of his Companie used to dine and sup within the hollownesse of that tree; where the very leaves yeelded of the own sufficient bed and bench room to rest and repose themselves."

Record trees are also quoted in Greece, Constantinople, and Samarkand, where the immense girths of $37 \mathrm{ft}$. and $39 \mathrm{ft}$. were attained.

\section{Earl Sandwich in the year 1739 directed attention to}

"the great Plane of the island Stanchio (anciently Cos). . is remarkable for its size and the care with which the natives have attempted to preserve it. It has stood for time immemorial in the chief town of the island, and while it is the boast of the inhabitants, it is also, and with justice, the wonder of strangers."

\section{He also remarked}

"Among the curiosities of this city is a Sycamore-tree, which is, without doubt, the largest in the known world ... from the outside verge of which, to the trunk, I measured forty-five large paces."

It is supposed that early botanists mistook the Acer pseudoplatanus for the fig-tree, or gave it this name on account of its resemblance. It seems more likely, however, that the tree they saw was the plane tree. That which we call sycamore the Americans more correctly term the great maple. In bark and timber, in flower and seed, there is no resemblance whatever between the Acer pseudoplatanus and the $P$. orientalis. According to Sargent, Acer is the classic name of the maple tree, and Platanus is the name of the plane tree. In America all the timber of the Acer species is called maple, and that of the Platanus sycamore. In Scotland the produce of Acer pseudoplatanus is called plane. The resulting confusion can easily be understood.

Throughout France and Germany the value of the timber produced by the plane tree has always been recognized. Not only were the trunks of the trees utilized with the utmost economy, but even the limbs have been carefully converted and put to useful purpose for furniture, floorings, and interior decoration. In America, also, its value has been fully realized, and the wood has been quarter sawn, which displays handsome marking, and earned the name of 'lace-wood', by which it is well known to
American craftsmen and in their export trade. It is only in England that the wood has been entirely wasted except as fuel.

The original oak panelling, comprising hall, stair. case, and doors in a country mansion damaged in the course of the War of 1914-18 was replaced by American 'lace-wood', but while all who saw the woodwork admired it, not even the owner knew its name or origin.

Magnificent fully grown specimens of this particularly graceful tree can be found in abundance scattered throughout England, Scotland, and Wales, and roadside planting has been steadily carried out in all our towns and villages. In other directions, however, unfortunately, for more than a hundred years big-scale planting has been neglected.

\section{SCIENCE AND THE WAR EFFORT}

THE meetings on "Science and Victory" arranged 1 by the Association of Scientific Workers in Londion on July 11, which took place simultaneously with one in Moscow, well emphasize the critical importance of science in the war effort of both nations and the determination of scientific workers to see that the fullest possible use is made of the scientific resources available. Copies of the addresses given have been made available by the Association.

Sir Robert Watson-Watt in his chairman's address put the essential point squarely enough : no military operation to-day can be a sustained success without applied science. Important and essential as are the other factors, without science they are not enough. Moreover, as other speakers pointed out, it is not merely the part of science in production, in the manufacture of munitions of all kinds and in the development of new weapons and of instruments of ever greater precision that is vital : a new scien. tific function-that of operational research-has emerged in Britain and in the United States, and in Soviet Russia appears to have existed before the outbreak of war.

Prof. J. D. Bernal's picture of these developments is highly suggestive. Operational research is no longer limited to the technical performance of weapons in the field under the supervision of those competent to assess performance and suggest effective improvements. Strategy as well as tactics has come under scientific surveillance on the field of battle itself. The processes of warfare itself, the effectiveness of various forms of attack and defence are being studied by specially trained men of science, and the results are being analysed and translated into improved tactical methods and weapons. In all this, Soviet Russia appears to have been a pioneer, though both countries are now using men of science for similar extended functions.

In Great Britain, at the present time, as Prof. Bernal suggests, the novelty of the military and operational use of scientific workers is attracting more attention and overshadowing some of the equally important achievements of science, no less vital to our war effort; in the fields of agriculture, nutrition and food supply, and health, it has provided substitutes for essential commodities of which we have been deprived or restricted by the War, especially in the Far East. The post-war consequences of these developments may well be highly important. It was natural for a meeting of scientific workers to 